\title{
URINE NEUTROPHIL GELATINASE-ASSOCIATED LIPOCALIN AS AN EARLY BIOCHEMICAL MARKER OF MICROALBUMINURIA IN PREDICTING EARLY KIDNEY DAMAGE IN PATIENTS WITH TYPE 2 DIABETES MELLITUS
}

\author{
P. J. PADMINI, V. ASHOK \\ Shri Sathya Sai Medical College and Research Institute, Sri Balaji \\ Vidyapeeth Deemed to be University, Tamilnadu, India; \\ e-mail: dr.ashokmbbs1986@gmail.com
}

Received: 08 July 2021; Accepted: 12 November 2021

\begin{abstract}
Diabetic nephropathy is one of the microvascular complications of diabetes mellitus. The study was done to evaluate the diagnostic value of neutrophil gelatinase-associated lipocalin (NGAL) urine level as a biomarker for the early detection of nephropathy in type 2 diabetic patients. This study was performed on 150 patients with type 2 diabetes mellitus classified into three equal groups according to their urine albumin/ creatinine ratio (ACR), including patients with normoalbuminuria (ACR $<30 \mathrm{mg} / \mathrm{g}$ creatinine), microalbuminuria (ACR $=30-300 \mathrm{mg} / \mathrm{g}$ creatinine) and macroalbuminuria (ACR $>300 \mathrm{mg} / \mathrm{g}$ creatinine). Fifty apparently healthy subjects were selected as a control group. Urine NGAL was estimated by a particle-enhanced turbidimetric immunoassay using Hitachi 917 analyzer. The serum level of glucose and creatinine was also estimated. The results showed that NGAL urine level was significantly elevated in diabetes patient groups with microalbuminuria and macroalbuminuria when compared to the control group and diabetes patient group with normoalbuminuria. The levels of urine NGAL correlated positively with microalbuminuria in patients with diabetes. Receiver operating characteristic curves revealed that urine NGAL had a higher diagnostic value for diabetic nephropathy early detection compared to ACR and microalbuminuria in patients with diabetes mellitus.
\end{abstract}

Keywords: gelatinase-associated lipocalin, diabetic nephropathy, albumin/creatinine ratio microalbuminuria.

$\mathrm{D}$ iabetes is a common endocrine disorder because of its worldwide increase in the prevalence rate. It subsequently increases incidence of macrovascular and microvascular complications including diabetic nephropathy (DN) [1].

Diabetes is found to be the major cause of end stage renal disease (ESRD) in patients who undergo dialysis [2, 3]. In a study from India, $46 \%$ of diabetic patients were found to have chronic kidney disease (CKD) [4].

DN is characterized by hypertension, albuminuria and decrease in glomerular filtration rate (GFR) leading to ESRD. DN is primarily a glomerular disorder but the decline in GFR is associated with severity of tubulointerstitial fibrosis and it is pro- posed to be a better predictor of DN than glomerular damage $[5,6]$.

The screening of DN is mainly based on assessment of microalbuminuria which is due to diabetes induced glomerular damage. The diagnostic accuracy of microalbuminuria in DN is being challenged by a large number of studies worldwide and it is being proposed that alternative biomarkers are also required for earlier identification of DN. The reason behind this is even diabetic patients with normoalbuminuria can develop significant degree of renal impairment [7, 8].

Recent studies have reported that the pathological changes in DN are associated with derangements in the glomerular and tubular compartments of the

(C) 2021 Padmini P.J., Ashok V. This is an open-access article distributed under the terms of the Creative Commons Attribution License, which permits unrestricted use, distribution, and reproduction in any medium, provided the original author and source are credited. 
kidney. Renal tubular and glomerular injury plays a major role in the development of $\mathrm{DN}$ and various biomarkers have been assessed for earlier detection of DN $[9,10]$.

Among them, neutrophil gelatinase-associated lipocalin (NGAL) seems to be a promising biomarker which is a $25 \mathrm{kDa}$ protein with 178 aminoacids. It belongs to the lipocalin family of proteins and it is produced by renal tubules whenever there is structural injury to kidney [11].

In comparison to routine markers of renal function such as serum creatinine, cystatin $\mathrm{C}$ or urea, NGAL primarily reflects the structural damage of renal tubular cells. Also, serum creatinine which is done in most of the hospitals and considered to have a major diagnostic value in CKD cannot be taken solely as a marker since it is influenced by many other factors like age, muscle mass, race etc [12].

NGAL was found to be effective in early diagnosis of Acute Kidney Injury (AKI) following nephrotoxic insults like sepsis, cardiac surgery and following administration of contrast agents [13, 14]. Little research has been done about their role as early markers in diabetic patients.

This study was conducted to assess the urinary levels of NGAL in patients with type 2 diabetes mellitus to detect early kidney damage and correlate them with microalbuminuria.

\section{Materials and Methods}

This study was conducted in the Department of Biochemistry at Karpagam faculty of medical sciences and research. This study was approved by the Institutional Ethics Committee, Karpagam faculty of medical sciences and research, Coimbatore study.

Study design. Hospital based cross sectional

Sample size: 150 (calculated by 4pq/d2; where $\mathrm{p}$ is prevalence).

Study group. Patients with type 2 diabetes mellitus attending diabetic clinic at Karpagam Medical College during the study period.

Diabetes patients were classified into three groups according to their albumin/creatinine ratio (ACR) as follows. Group I (Normoalbuminuria): 50 diabetes patients with ACR $<30 \mathrm{mg} / \mathrm{g}$ of creatinine. Group II (Microalbuminuria): 50 diabetes patients with ACR 30-300 mg/g of creatinine. Group III (Macroalbuminuria): 50 diabetes patients with ACR > $300 \mathrm{mg} / \mathrm{g}$ of creatinine. Group IV (controls): 50 healthy subjects were selected as control group.
Inclusion criteria. Patients with type 2 diabetes mellitus ( $>5$ yrs duration) according to American Diabetes Association (ADA) criteria.

Exclusion criteria. Patients with cardiovascular disorders (like CCF, H/o. CAD); pulmonary disorders (like respiratory failure); infections (Urinary tract infection) \& inflammatory states; febrile illness; cancer; severe renal impairment (eGFR $<30 \mathrm{ml} /$ min) and vigorous exercise.

Subjects who fulfilled the inclusion and exclusion criteria were included in the study. After explaining the nature of the study, written consent was obtained from all subjects before collecting blood sample.

Anthropometric measurements. Body mass was measured to the nearest $0.1 \mathrm{~kg}$, with the participants dressed in light clothing. Barefoot standing height was measured to the nearest $0.1 \mathrm{~cm}$ with a wall-mounted stadiometer. Body mass index (BMI) is used for the assessment of fat distribution and obesity. Using standard measures of height and weight, BMI was measured using Quetelet's index (BMI = weight $(\mathrm{kg}) /$ height $\left(\mathrm{m}^{2}\right)$ [15].

Sample collection. First morning void urine samples (mid-stream urine) was obtained to measure urine albumin, microalbumin, creatinine and NGAL.

Two ml of whole blood was collected from the subjects in fasting state. Then the serum was separated after subjecting the collected blood to centrifugation at $2500 \mathrm{rpm}$ for $5 \mathrm{~min}$ at room temperature. The serum was divided into four aliquots and stored at $-20^{\circ} \mathrm{C}$ for analysis of creatinine and fasting plasma glucose.

Estimation of biochemical parameters. Estimation of plasma glucose was done by glucoseoxidase method using fully automated analyser [16]. Estimation of creatinine was done by modified Jaffe's method using fully automated analyser [17]. Urine NGAL is estimated by a particle-enhanced turbidimetric immunoassay using Hitachi 917 analyzer. Microalbuminuria was estimated by immunoturbidimetry method using Hitachi 917 analyser. ACR was measured by urine albumin (mg/dl)/ urine creatinine $(\mathrm{mg} / \mathrm{dl}) \times 1000$.

Statistical analysis. Statistical Package for Social Sciences (SPSS, USA) was used to do the statistical analysis. All parameters were presented as mean \pm SD. Student's $t$-test was used for comparing the means of continuous variables.

One-way analysis of variance (ANOVA) was done to compare the differences of parameters among various groups. Post hoc testing was done to 
compare the difference among the studied groups. The correlations between various variables were calculated using the Pearsons correlation analysis. A receiver operating characteristic (ROC) analysis was done to calculate the area under the curve (AUC) and find the best diagnostic efficacy of each parameter. A linear regression analysis was performed to evaluate interrelationship between urinary NGAL, ACR and microalbuminuria. A $P<0.05$ was taken as statistically significant.

\section{Results}

The comparison of demographic and baseline characteristics of the study population are shown in Table 1. Of 200 study participants, there were 50 normoalbuminuric with diabetes, 50 microalbuminuric with diabetes, 50 macroalbuminuric with diabetes, and 50 control populations. The anthropometric measures like height, weight, body mass index showed no statistically significant difference between the various diabetes groups and controls.
FBS were progressively higher among normoalbuminuria, microalbuminuria, andmacroalbuminuria. Systolic blood pressure was significantly higher in the marcoalbuminuria group compared to the diabetes patients with normoalbuminuria and normal healthy controls.

Urinary NGAL were significantly higher in the diabetes groups compared to the control group. Multiple comparisons indicated the significant difference in urinary NGAL values between the groups $(P<0.05)$ (Table 2). Intergroup comparison among three groups of diabetes patients showed that difference was significant with highest mean value in macroalbuminuria group and lowest in normoalbuminuria group.

Microalbumin was significantly high in diabetes patients with microalbuminuria and macroalbuminuria compared to the controls. Urinary ACR was significantly increased in diabetes patients with normoalbuminuria, microalbuminuria and macroalbuminuria compared to normal controls.

Ta b le 1. Comparison of demographics and baseline characteristics among various groups

\begin{tabular}{l|c|c|c|c|c}
\hline \multicolumn{1}{c|}{ Variables } & Group I & Group II & Group III & Control group & $P$ Value \\
\hline Age (years) & $42.16 \pm 3.96$ & $43.02 \pm 3.71$ & $43.36 \pm 3.65$ & $43.18 \pm 3.48$ & 0.74 \\
Height (m) & $1.58 \pm 0.08$ & $1.56 \pm 0.07$ & $1.58 \pm 0.08$ & $1.57 \pm 0.07$ & 0.80 \\
Weight $(\mathrm{kg})$ & $56.94 \pm 6.00$ & $56.52 \pm 6.71$ & $59.12 \pm 6.38$ & $56.04 \pm 4.37$ & 0.98 \\
BMI $\left(\mathrm{kg} / \mathrm{m}^{2}\right)$ & $22.82 \pm 2.04$ & $23.03 \pm 2.16$ & $23.74 \pm 2.62$ & $22.76 \pm 1.76$ & 0.96 \\
Systolic Bp (mm/Hg) & $117.88 \pm 6.64$ & $119.44 \pm 7.86$ & $123.92 \pm 5.75$ & $111.68 \pm 9.64$ & $0.01^{*, \neq}$ \\
Diastolic Bp (mm/Hg) & $71.36 \pm 7.21$ & $72.36 \pm 7.98$ & $83.80 \pm 15.84$ & $70.04 \pm 6.93$ & $0.00^{*}$ \\
FBS(mg/dl) & $96.44 \pm 6.18$ & $102.04 \pm 9.69$ & $123.44 \pm 15.70$ & $87.04 \pm 9.30$ & $0.001^{*,+\neq}$ \\
\hline
\end{tabular}

Data are presented as mean $\pm \mathrm{SD} .{ }^{*} P \leq 0.05$ is statistically significant. ANOVA test was used to analyse the data. BMI body mass index, FBS - fasting blood sugar, BP - blood pressure. *Significant difference between Group III and controls $(P<0.05)$. ${ }^{\dagger}$ Significant difference between Group III and Group II $(P<0.05)$. ${ }^{*}$ Significant difference between Group III and Group I $(P<0.05)$

Ta b le 2. Comparison of clinical parameters among various groups

\begin{tabular}{l|c|c|c|c|c}
\hline \multicolumn{1}{c|}{ Parameters } & Group I & Group II & Group III & Control group & $P$ Value \\
\hline Serum creatinine (mg/dl) & $0.89 \pm 0.17$ & $1.25 \pm 0.21$ & $1.73 \pm 0.32$ & $0.83 \pm 0.15$ & $0.001^{*,+, \neq}$ \\
Microalbumin (mg/l) & $18.96 \pm 7.66$ & $91.76 \pm 60.98$ & $508.66 \pm 156.56$ & $14.04 \pm 6.42$ & $0.001^{*,+, \neq}$ \\
ACR (mg/g) & $25.11 \pm 5.67$ & $120.60 \pm 41.18$ & $715.19 \pm 143.21$ & $6.64 \pm 1.56$ & $0.001^{*,+, \neq}$ \\
uNGAL (ng/ml) & $41.57 \pm 14.84$ & $97.32 \pm 31.26$ & $290.50 \pm 92.98$ & $12.26 \pm 6.78$ & $0.001^{*,+, \neq}$ \\
\hline
\end{tabular}

Data are presented as mean \pm SD. $P \leq 0.05$ is statistically significant. ANOVA test was used to analyse the data. ACR Albumin creatinine ratio, uNGAL - urinary neutrophil gelatinase associated lipocalin. *Significant difference between Group III and controls $(P<0.05)$. ${ }^{\dagger}$ Significant difference between Group III and Group II $(P<0.05)$. ${ }^{\text {*Significant differ- }}$ ence between Group III and group I $(P<0.05)$ 
Association of urinary NGAL with microalbuminuria, ACR and serum creatinine in type 2 diabetes patients. Pearson's correlation was done to find the correlation of urinary NGAL with microalbuminuria, ACR and serum creatinine in patients with diabetes. The urinary NGAL showed good $(P<0.001)$ positive correlation with Microalbuminuria $(r=0.876)$, ACR $(r=0.833)$ and with serum creatinine $(r=0.724)$ (Table 3).

Linear regression analysis to find the effect of microalbuminuria on urinary NGAL and ACR among the diabetes patients. Linear regression analysis was performed to find the interrelationship between urinary NGAL, ACR and microalbuminuria. Regression analysis with urinary NGAL as dependent variable expressed a significant linear positive relationship with microalbuminuria (Table 4 and Fig. 1). Regression analysis with ACR as a dependent variable showed a significant relationship with microalbuminuria (Table 4 and Fig. 2).

Receiver operating characteristics curve analysis of urinary NGAL, microalbuminuria and $A C R$. Receiver operating characteristics (ROC) curve analysis was carried out to find the diagnostic efficacy of urinary NGAL, microalbuminuria and ACR in identifying the patients with DN (Table 5 and Fig. 3). The urinary NGAL showed a very good diagnostic profile, describing an AUC of 0.942 (95\% CI: $0.902-0.981, P<0.001)$ with a best cutoff value of $86.29 \mathrm{ng} / \mathrm{ml}$ (sensitivity $85 \%$; specificity $72 \%$ ). This is followed by ACR, showing an AUC of 0.855 (95\% CI: 0.793-0.916, $P<0.001$ ) and a best cutoff value of 114.6 (sensitivity $84 \%$; specificity $79 \%$ ). Microalbuminuria had an AUC of 0.874 (95\% CI: 0.82$0.92, P<0.001$ ) and a best cutoff value of $72.4 \mathrm{mg} / \mathrm{dl}$ (sensitivity $82 \%$; specificity $70 \%$ ).

\section{Discussion}

Diabetic nephropathy is a metabolic syndrome characterized by presence of macroalbuminuria, a
Table 3. Correlation analysis of NGAL with Microalbuminuria, ACR and serum creatinine in type 2 diabetes patients

\begin{tabular}{l|c|c}
\hline \multicolumn{1}{c|}{ Variables } & $R$ value & $P$ Value \\
\hline Microalbumin & 0.876 & 0.001 \\
ACR & 0.833 & 0.001 \\
Serum creatinine & 0.724 & 0.001 \\
\hline
\end{tabular}

Pearson correlation analysis was performed to analyze the data. ${ }^{*} P<0.05$ is considered statistically significant. ACR - albumin creatinine ratio, uNGAL - urinary neutrophil gelatinase associated lipocalin

slow and progressive decline in glomerular filtration rate, elevated blood pressure, and increased cardiovascular mortality. Renal histopathologic changes in diabetes include glomerular basement membrane thickening, glomerular hypertrophy, mesangial cell expansion, podocyte injury, hyalinosis, and thickening of the afferent and efferent arterioles [18].

Diabetes patients are constantly exposed to hemodynamic and metabolic stress. Hemodynamic stress mainly leads to hypertension. Metabolic stress is closely related to hyperlipidemia and hyperglycemia. Hypertension, hyperglycemia and hyperlipidemia together leads to tubulointerstitial damage, endothelial dysfunction and atherosclerosis. Endothelial dysfunction progresses to albuminuria in patients with diabetes whereas tubular damage of the kidney leads to increase in the tubular biomarkers [19].

A study by Yaqoob $\mathrm{M}$ et al. showed that tubular injury and endothelial dysfunction may precede the onset of microalbuminuria in patients with diabetes mellitus. Diabetes patients with even normal eGFR are at greater risk for AKI compared to normal healthy subjects [20]. Renal tubular markers such as NGAL, MCP (Monocyte chemoattractant protein-1), KIM-1 (Kidney injury molecule 1), urinary liver

Table 4. Linear regression analysis to find the effect of Microalbuminuria on urinary NGAL and ACR among the diabetes patients

\begin{tabular}{l|c|c|c|c}
\hline Independent variables & $\begin{array}{c}\text { Nonstandardised } \\
\text { coefficients } \\
\text { B value }\end{array}$ & $\begin{array}{c}\text { Standardised } \\
\text { coefficients } \beta\end{array}$ & R square value & P value \\
\hline uNGAL & 0.488 & 0.876 & 0.767 & 0.001 \\
ACR & 1.162 & 0.866 & 0.749 & 0.001 \\
\hline
\end{tabular}

${ }^{*} P<0.05$ is considered statistically significant. ACR - albumin creatinine ratio, uNGAL - urinary Neutrophil gelatinase associated lipocalin 


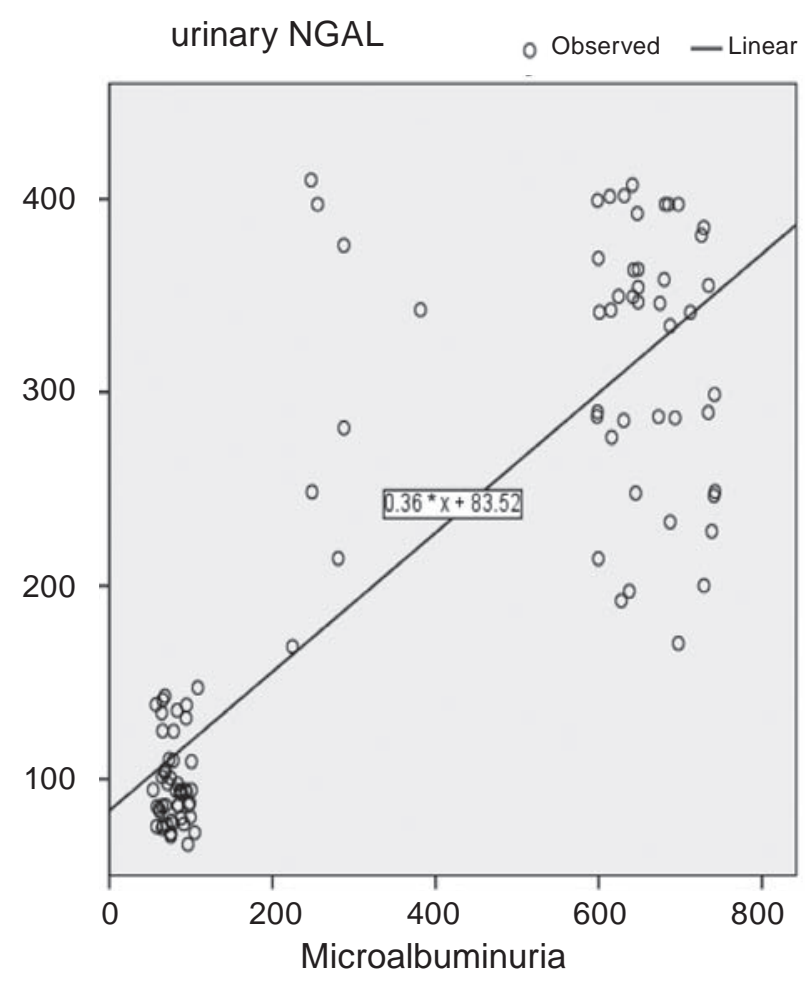

Fig. 1. Linear regression analysis between microalbuminuria and urinary NGAL among the diabetes cases

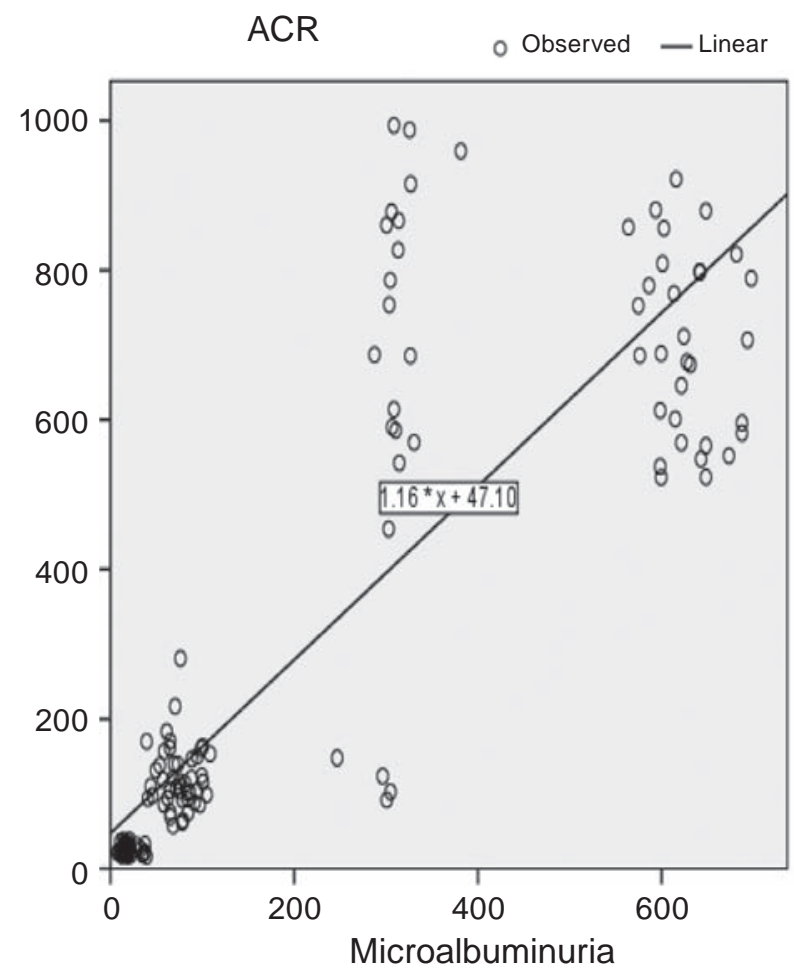

Fig. 2. Linear regression analysis between microalbuminuria and ACR among the diabetes cases

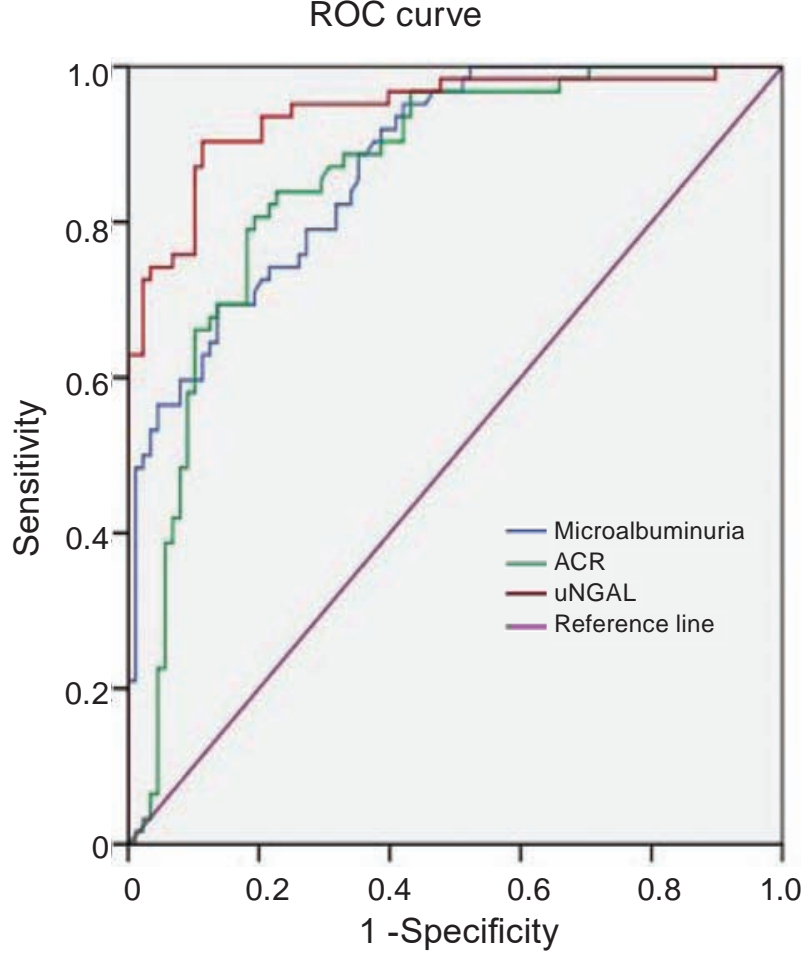

Fig. 3. ROC curve of urinary NGAL, Microalbuminuria, and ACR

type fatty acid binding protein (ULFABP) are used to predict the onset and progression of DN [21-24].

NGAL is a $25 \mathrm{kDa}$ protein consisting of a polypeptide chain of 178 amino acids and belongs to the 'lipocalin' superfamily. It is expressed by neutrophils and various epithelial cells. This protein is released in blood and urine following ischemic and nephrotoxic injury from the tubular cells. Variable degrees of NGAL gene expression is demonstrated in human tissues like uterus, prostate, salivary glands, lung, trachea, stomach, colon, and kidney [25].

NGAL is currently considered as one of the most promising biomarkers in clinical nephrology and has been extensively studied in acute kidney disease. A few studies have demonstrated that NGAL might also be elevated in some other conditions other than renal injury. Therefore, we have excluded those patients with infection, neoplasia and inflammation $[25,26]$.

High glucose levels and diabetic substrates, including advanced glycation end-products, carbonyl intermediates, and growth factors, promote renal tubular hypertrophy and fibrosis. Therefore, tubular biomarkers may be crucial as glomerular markers 
Ta b le 5. Receiver operating characteristics curve analysis of urinary NGAL, Microalbuminuria, and ACR

\begin{tabular}{l|c|c|c|c|c}
\hline \multirow{2}{*}{ Variables } & \multirow{2}{*}{ Area } & \multirow{2}{*}{ Standard error } & \multirow{2}{*}{ Asymptotic Sig } & \multicolumn{2}{|c}{ Asymptotic 95\% confidence interval } \\
\cline { 5 - 6 } & & & & Lower Bound & Upper Bound \\
\hline uNGAL & 0.942 & 0.020 & $0.001^{*}$ & 0.902 & 0.981 \\
ACR & 0.855 & 0.031 & $0.001^{*}$ & 0.793 & 0.916 \\
Microalbumin & 0.874 & 0.027 & $0.001^{*}$ & 0.821 & 0.927 \\
\hline
\end{tabular}

${ }^{*} P<0.05$ is considered statistically significant. ACR - albumin creatinine ratio, uNGAL - urinary Neutrophil gelatinase associated lipocalin

for early diagnosis of renal impairment in patients with diabetes [27, 28]. As NGAL is a marker of distal tubular injury, it is not going to be affected by albuminuria or proteinuria, which suggests that tubular injury may occur before glomerular injury in patients with type 2 diabetes [10]. Markers of tubular injury predicting onset of albuminuria and progression of diabetes have been observed in various other studies using other biomarkers such as ULFABP, MCP, KIM-1 [22-24].

But a study by Kim et al. suggested that there was no significant difference in NGAL levels among normoalbuminuria, microalbuminuria and control group which contradicts the role of NGAL as an early biomarker of DN [29].

In our study, the urinary NGAL levels were significantly elevated in microalbuminuria and macroalbuminuria diabetes patient groups when compared to the control. Urine NGAL showed a positive correlation relationship with microalbuminuria in diabetic patients which indicates urinary NGAL was positively correlated with the progression of $\mathrm{DN}$.

Bolignano et al found that serum and urinary NGAL were significantly elevated in diabetic patients compared to the control group and that NGAL levels were elevated in diabetic patients without early signs of glomerular damage [30].

Nielsen et al reported that elevated urine NGAL in type 1 diabetic patients with or without albuminuria indicates tubular damage [24]. A study by Jiao et al showed increased levels of NGAL in both serum and urine, which correlated with the severity of renal damage in patients with diabetes mellitus. He also suggested that NGAL is elevated both in serum and urine, even before albumin appears in urine [31].

Nauta et al showed that NGAL is increased in diabetes patients with normoalbuminuria when compared to the controls [10]. Lacquaniti et al. suggested that NGAL is elevated in diabetes patients even before diagnosis of albuminuria and hence NGAL can be used for the detection of early kidney involvement of normoalbuminuric DN [32].

Zachwieja et al. found that urine and serum NGAL were significantly increased in diabetes children with normoalbuminuria, and also suggested that normoalbuminuria does not exclude DN [33].

Normoalbuminuric diabetes patients had significantly greater mean urinary NGAL levels than the controls which suggests that tubular injury may occur before the onset of glomerular injury in patients with diabetes. This suggests that tubular dysfunction is due to hemodynamic and metabolic stress which is secondary to chronic hyperglycemia in patients with diabetes mellitus [34, 35].

This finding supports the hypothesis that urine NGAL can be used as a marker for the early detection of diabetic nephropathy. Besides, the mean value of urine NGAL was also observed to be increased according with the degree of renal impairment. This finding indicates that urine NGAL can also be used in determining the severity of renal disease.

ROC curve analysis was done to compare the diagnostic performance of NGAL, microalbuminuria and ACR and to find which is more sensitive and specific in the diagnosis of DN. Urinary NGAL had a higher diagnostic performance of diabetic nephropathy compared to ACR and microalbuminuria.

Microalbuminuria is considered as the earliest marker of development of diabetic nephropathy and is usually associated with significant glomerular damage. However, recent studies showed that microalbuminuria does not necessarily reflect permanent renal impairment. In addition, several studies suggest that early structural damage in both glomerular and tubular compartments may be even present in subjects with normoalbuminuria.

Urinary NGAL measurement is more sensitive than microalbumin and can be a useful tool for evaluating early renal involvement in patients with diabetes. 
Limitations of the study. Major limitation of our study was small sample size. It is a single centre study with cross-sectional design. We did not collect 24 hour urine sample due to technical difficulties in collecting sample.

Conclusion. Urinary NGAL has a positive association with microalbuminuria and it can be a noninvasive tool for diagnosis and monitoring the progression of diabetic nephropathy. Urinary NGAL measurement is more sensitive than microalbumin and can be used as an important tool for detecting early renal involvement in patients with diabetes mellitus even earlier to incipient nephropathy.

Conflict of interest. Authors have completed the Unified Conflicts of Interest form at http://ukrbiochemjournal.org/wp-content/uploads/2018/12/ coi_disclosure.pdf and declare no conflict of interest.

\section{НЕЙТРОФІЛЬНИЙ ЖЕЛАТИНАЗО- АСОЦІЙОВАНИЙ ЛІПОКАЛІН СЕЧІ, ЯК БІОХІМІЧНИЙ МАРКЕР МІКРОАЛЬБУМІНУРІЇ ДЛЯ РАННЬОГО ВИЯВЛЕННЯ НЕФРОПАТІЇ У ПАЦІЕНТІВ ІЗ ЦУКРОВИМ ДІАБЕТОМ 2 ТИПУ}

\author{
P. J. Padmini, V. Ashok ${ }^{\bowtie}$ \\ Shri Sathya Sai Medical College and Research \\ Institute, Sri Balaji Vidyapeeth Deemed \\ to be University, Tamilnadu, India; \\ 凶e-mail: dr.ashokmbbs1986@gmail.com
}

Діабетична нефропатія $є$ одним із мікросудинних ускладнень цукрового діабету. Метою дослідження було оцінити діагностичну цінність рівня нейтрофільного желатиназоасоційованого ліпокаліну (NGAL) у сечі як біомаркера для раннього виявлення нефропатії у пацієнтів із цукровим діабетом 2 типу. У дослідженні взяли участь 150 пацієнтів із діабетом 2 типу, яких розділили на 3 рівні групи відповідно до альбумін/креатинінового співвідношення в сечі (ACR), у тому числі пацієнти 3 нормоальбумінурією (ACR < 30 мг/г креатиніну), мікроальбумінурією (ACR $=30$ 300 мг/Г креатиніну) та макроальбумінурією (ACR > 300 мг/г креатиніну). До контрольної групи було відібрано 50 здорових осіб. NGAL у сечі визначали методом турбодиметричного імуноаналізу на аналізаторі Hitachi 917. Також оцінювали рівень глюкози та креатиніну у сироватці крові. Виявлено, що рівень NGAL у сечі був значно підвищений у групах хворих на діабет із мікроальбумінурією та макроальбумінурією у порівнянні 3 контрольною групою та групою хворих на діабет 3 нормоальбумінурією. Рівень NGAL у сечі позитивно корелював із мікроальбумінурією у пацієнтів із діабетом. Показано, що визначення NGAL у сечі пацієнтів із діабетом має вищу діагностичну цінність для раннього виявлення діабетичної нефропатії у порівнянні з визначенням альбумін-креатинінового співвідношення та мікроальбумінурією.

К лючов і с лов а: желатиназоасоційований ліпокалін, діабетична нефропатія, альбумін/креатинінове співвідношення, мікроальбумінурія.

\section{References}

1. Fowler MJ. Microvascular and Macrovascular Complications of Diabetes. Clin Diabet. 2008; 26(2): 77-82.

2. Stanton RC. Clinical challenges in diagnosis and management of diabetic kidney disease. $\mathrm{Am} \mathrm{J}$ Kidney Dis. 2014; 63(2 Suppl 2): S3-S21.

3. O'Hare AM, Bertenthal D, Covinsky KE, Landefeld CS, Sen S, Mehta K, Steinman MA, Borzecki A, Walter LC. Mortality risk stratification in chronic kidney disease: one size for all ages? J Am Soc Nephrol. 2006; 17(3): 846-853.

4. Reutens AT. Epidemiology of diabetic kidney disease. Med Clin North Am. 2013; 97(1): 1-18.

5. Bonventre JV. Can we target tubular damage to prevent renal function decline in diabetes? Semin Nephrol. 2012; 32(5): 452-462.

6. De Carvalho JAM, Tatsch E, Hausen BS, Bollick YS, Moretto MB, Duarte T, Duarte MMMF, Londero SWK, Premaor MO, Comim FV, Delanghe JR, Moresco RN. Urinary kidney injury molecule-1 and neutrophil gelatinase-associated lipocalin as indicators of tubular damage in normoalbuminuric patients with type 2 diabetes. Clin Biochem. 2016; 49(3): 232-236.

7. Prasannakumar $M$, Rajput R, Seshadri K, Talwalkar P, Agarwal P, Gokulnath G, Kotak B, Raza A, Vasnawala H, Teli C. An observational, cross-sectional study to assess the prevalence of chronic kidney disease in type 2 diabetes patients in India (START -India). Indian $J$ Endocrinol Metab. 2015; 19(4): 520-523. 
8. MacIsaac RJ, Tsalamandris C, Panagiotopoulo S, Smith TJ, McNeil KJ, Jerums G. Nonalbuminuric renal insufficiency in type 2 diabetes. Diabetes Care. 2004; 27(1): 195-200.

9. Phillips AO. The role of renal proximal tubular cells in diabetic nephropathy. Curr Diab Rep. 2003; 3(6): 491-496.

10. Nauta FL, Boertien WE, Bakker SJL, van Goor H, van Oeveren W, de Jong PE, Bilo H, Gansevoort RT. Glomerular and tubular damage markers are elevated in patients with diabetes. Diabetes Care. 2011; 34(4): 975-981.

11. Schmidt-Ott KM, Mori K, Li JY, Kalandadze A, Cohen DJ, Devarajan P, Barasch J. Dual action of neutrophil gelatinase-associated lipocalin. $J$ Am Soc Nephrol. 2007; 18(2): 407-413.

12. Baxmann AC, Ahmed MS, Marques NC, Menon VB, Pereir AB, Kirsztajn GM, Heilberg IP. Influence of muscle mass and physical activity on serum and urinary creatinine and serum cystatin C. Clin J Am Soc Nephrol. 2008; 3(2): 348-354.

13. Han WK, Wagener G, Zhu Y, Wang S, Lee HT. Urinary biomarkers in the early detection of acute kidney injury after cardiac surgery. Clin $J$ Am Soc Nephrol. 2009; 4(5): 873-882.

14. Haase M, Bellomo R, Devarajan P, Schlattmann P, Haase-Fielitz A, NGAL Meta-analysis Investigator Group. Accuracy of neutrophil gelatinase-associated lipocalin (NGAL) in diagnosis and prognosis in acute kidney injury: a systematic review and meta-analysis. $\mathrm{Am} J$ Kidney Dis. 2009; 54(6): 1012-1024.

15. Paccaud F, Schlüter-Fasmeye V, Wietlisbach V, Bovet P. Dyslipidemia and abdominal obesity: an assessment in three general populations. $J$ Clin Epidemiol. 2000; 53(4): 393-400.

16. Beach EF, Turner JJ. An enzymatic method for glucose determination in body fluids. Clin Chem. 1958; 4(6): 462-475.

17. Moss GA, Bondar RJ, Buzzelli DM. Kinetic enzymatic method for determining serum creatinine. Clin Chem. 1975; 21(10): 1422-1426.

18. Bacci MR, Chehter EZ, Azzalis LA, Costa de Aguiar Alves B, Fonseca FLA. Serum NGAL and Cystatin C Comparison With Urinary Albumin-to-Creatinine Ratio and Inflammatory Biomarkers as Early Predictors of Renal Dysfunction in Patients With Type 2 Diabetes. Kidney Int Rep. 2016; 2(2): 152-158.

19. Kaul A, Behera MR, Rai MK, Mishra P, Bhaduaria DS, Yadav S, Agarwal V, Karoli R,
Prasad N, Gupta A, Sharma RK. Neutrophil Gelatinase-associated Lipocalin: As a Predictor of Early Diabetic Nephropathy in Type 2 Diabetes Mellitus. Indian J Nephrol. 2018; 28(1): 53-60.

20. Yaqoob M, Patrick AW, McClelland P, Stevenson A, Mason H, White MC, Bell GM. Relationship between markers of endothelial dysfunction, oxidant injury and tubular damage in patients with insulin-dependent diabetes mellitus. Clin Sci (Lond). 1993; 85(5): 557-562.

21. Ronco C. N-GAL: diagnosing AKI as soon as possible. Crit Care. 2007;11(6):173.

22. Panee J. Monocyte Chemoattractant Protein 1 (MCP-1) in obesity and diabetes. Cytokine. 2012; 60(1): 1-12.

23. Nielsen SE, Sugaya T, Hovind P, Baba T, Parving HH, Rossing P. Urinary liver-type fatty acid-binding protein predicts progression to nephropathy in type 1 diabetic patients. Diabetes Care. 2010; 33(6): 1320-1324.

24. Nielsen SE, Schjoedt KJ, Astrup AS, Tarnow L, Lajer M, Hansen PR, Parving HH, Rossing P. Neutrophil Gelatinase-Associated Lipocalin (NGAL) and Kidney Injury Molecule 1 (KIM1) in patients with diabetic nephropathy: a crosssectional study and the effects of lisinopril. Diabet Med. 2010; 27(10): 1144-1150.

25. Gazareen SS, Korani MAER, Tawfeek AR, Omar TA, Dwidar GIEA. Role of urinary neutrophil gelatinase-associated lipocalin in diabetic and nondiabetic patients with nephropathy. Menoufia Med J. 2021; 34(1): 135140.

26. Quang TH, Nguyet MP, Thao DP, Thi MH, Phuong Thi Dam L, Thi HH, Van AP, Luong TC, Tuyet MNT, Duy QD, Nhu BD, Duc TN. Evaluation of Urinary Neutrophil Gelatinase Associated Lipocalin and Kidney Injury Molecule-1 as Diagnostic Markers for Early Nephropathy in Patients with Type 2 Diabetes Mellitus. Diabetes Metab Syndr Obes. 2020; 13: 2199-2207.

27. Sun YM, Su Y, Li J, Wang LF. Recent advances in understanding the biochemical and molecular mechanism of diabetic nephropathy. Biochem Biophys Res Commun. 2013; 433(4): 359-361.

28. Currie G, McKay G, Delles C. Biomarkers in diabetic nephropathy: Present and future. World J Diabetes. 2014; 5(6): 763-776.

29. Kim SS, Song SH, Kim IJ, Yang JY, Lee JG, Kwak IS, Kim YK. Clinical implication of 
urinary tubular markers in the early stage of nephropathy with type 2 diabetic patients. Diabetes Res Clin Pract. 2012; 97(2): 251-257.

30. Bolignano D, Lacquaniti A, Coppolino G, Donato V, Fazio MR, Nicocia G, Buemi M. Neutrophil gelatinase-associated lipocalin as an early biomarker of nephropathy in diabetic patients. Kidney Blood Press Res. 2009; 32(2): 91-98.

31. Jiao LY, Guo Q, Song Z. Diagnostic value of urinary neutrophil gelatinase associated lipocalin and serum cystatin $\mathrm{C}$ on diabetic nephropathy. J Xinxiang Med Coll. 2011; (5): 21.

32. Lacquaniti A, Donato V, Pintaudi B, Di Vieste G, Chirico V, Buemi A, Di Benedetto A, Arena A, Buemi M. "Normoalbuminuric" diabetic nephropathy: tubular damage and NGAL. Acta Diabetol. 2013; 50(6): 935-942.
33. Zachwieja J, Soltysiak J, Fichna P, Lipkowska K, Stankiewicz W, Skowronska B, Kroll P, Lewandowska-Stachowiak M. Normal-range albuminuria does not exclude nephropathy in diabetic children. Pediatr Nephrol. 2010; 25(8): 1445-1451.

34. Assal HS, Tawfeek S, Rasheed EA, ElLebedy D, Thabet EH. Serum cystatin C and tubular urinary enzymes as biomarkers of renal dysfunction in type 2 diabetes mellitus. Clin Med Insights Endocrinol Diabetes. 2013; 6: 7-13.

35. Fathimah M, Alicezah MK, Thevarajah M. Neutrophil gelatinase-associated lipocalin (NGAL): An early marker for diabetic nephropathy. Int J Diabetes Dev Ctries. 2012; 32(1): 19-24. 